\title{
In vitro Fermentation Characteristics and Rumen Microbial Population of Diet Supplemented with Saccharomyces cerevisiae and Rumen Microbe Probiotics
}

\author{
L. Riyanti ${ }^{a}$, Suryahadi ${ }^{{ }^{*}}$, \& D. Evvyernie ${ }^{\mathrm{b}}$ \\ atudy Program of Nutrition and Feed Science, Faculty of Animal Science, Graduate School, \\ Bogor Agricultural University \\ ${ }^{b}$ Department of Nutrition and Feed Technology, Faculty of Animal Science, Bogor Agricultural University \\ Jalan Agatis, Kampus IPB Darmaga Bogor 16680, Indonesia \\ (Received 27-08-2015; Reviewed 25-09-2015; Accepted 04-12-2015)
}

\begin{abstract}
The objective of this study was to select three strains of probiotic Saccharomyces cerevisiae and to evaluate the effect of $S$. cerevisiae and rumen bacteria isolate (MR4) supplementation and their combination on rumen fermentability and rumen microbial population. Experiment 1 was designed in a $4 \times 5$ factorial randomized block design with 3 replications. The first factor was S. cerevisiae strain consisted of control treatment (without S. cerevisiae supplementation), NBRC 10217, NRRL Y 567 and NRRL 12618, and the second factor was incubation time consisted of $0,1,2,3$, and $4 \mathrm{~h}$. Ration was basal ration for feedlot with forage to concentrate ratio $(\mathrm{F}: \mathrm{C})=60: 40$. Dosage of each treatment with $S$. cerevisiae was $5 \mathrm{x}$ $10^{10} \mathrm{cfu} / \mathrm{kg}$ ration. Experiment 2 was designed in randomized block design with 4 treatments: $\mathrm{P}=$ basal ration of feedlot; $\mathbf{P 1}=\mathbf{P} 0+$ S. cerevisiae; $\mathbf{P 2}=\mathbf{P 0}+\mathrm{MR} 4$ isolate $\left(5 \times 10^{7} \mathrm{cfu} / \mathrm{kg}\right.$ ration $) ; \mathbf{P} 3=\mathbf{P 0}+$ S. cerevisiae and MR4 isolate. The result of experiment 1 showed that supplementation of S. cerevisiae NRRL 12618 had the highest $S$. cerevisiae population and increased rumen bacterial population. This strain was selected as probiotic in experiment 2 . The result from experiment 2 showed that probiotic supplementation stabilized rumen $\mathrm{pH}$ and produced the highest $\mathrm{NH}_{3}$ concentration $(\mathrm{P}<0.05)$ and bacterial population $(\mathrm{P}<0.05)$. As compared with control, all treatments reduced protozoa population $(\mathrm{P}<0.05)$. Combination of $S$. cerevisiae and MR4 probiotics produced the highest total volatile fatty acids (VFA) and isovalerate $(\mathrm{P}<0.05)$. It was concluded that strain S. cerevisiae NRRL 12618 had potential as probiotic yeast. Supplementation with this strain increased fermentability, rumen isoacid and decreased A:P ratio. Those abilities could be improved with MR4 rumen isolate probiotic.
\end{abstract}

Key words: probiotic, fermentation characteristics, rumen microbe, Saccharomyces cerevisiae

\section{ABSTRAK}

Penelitian bertujuan untuk menyeleksi tiga strain probiotik Saccharomyces cerevisiae, serta mengevaluasi pengaruh suplementasi probiotik $S$. cerevisiae dan isolat mikroba rumen (MR4) dan kombinasinya pada fermentabilitas dan populasi mikroba rumen secara in vitro. Percobaan dilakukan dalam dua tahap, Percobaan 1 dirancang dengan rancangan acak kelompok faktorial $4 \times 5$ dengan 3 ulangan. Faktor pertama adalah strain S. cerevisiae yang terdiri atas kontrol (tidak disuplementasi dengan S. cerevisiae), NBRC 10217, NRRL Y 567 and NRRL 12618, dan faktor kedua adalah waktu inkubasi, yaitu 0, 1, 2, 3, dan 4 jam. Ransum yang digunakan adalah ransum basal sapi pedaging dengan rasio $\mathrm{H}: \mathrm{K}=60: 40$. Dosis S. cerevisiae yang diberikan adalah $5 \times 10^{10} \mathrm{cfu} / \mathrm{kg}$ ransum. Percobaan 2 dirancang dengan rancangan acak kelompok dengan 4 perlakuan, yaitu: $\mathbf{P 0}=$ ransum basal untuk sapi feedlot; $\mathbf{P 1}=\mathbf{P 0}+$ S. cerevisiae; $\mathbf{P 2}=\mathbf{P 0}+$ isolat MR4 (dosis $5 \times 10^{7} \mathrm{cfu} / \mathrm{kg}$ ransum); dan $\mathrm{P3}=\mathrm{P0}+\mathrm{S}$. cerevisiae dan isolat MR4. Hasil percobaan 1 menunjukkan bahwa suplementasi S. cerevisiae NRRL 12618 memiliki laju pertumbuhan S. cerevisiae 3,3\%/jam. Strain ini terpilih sebagai probiotic yeast pada percobaan 2. Hasil percobaan 2 menunjukkan bahwa suplementasi probiotik masih dapat mempertahankan $\mathrm{pH}$ rumen normal, sehingga $\mathrm{pH}$ rumen lebih stabil dan berdampak pada peningkatan konsentrasi $\mathrm{NH}_{3}(\mathrm{P}<0,05)$, populasi bakteri rumen total $(\mathrm{P}<0,05)$ dan penurunan populasi protozoa $(\mathrm{P}<0,05)$. Kombinasi probiotik S. cerevisiae dan MR4 mampu meningkatkan konsentrasi volatile fatty acid (VFA) total dan isovalerat $(\mathrm{P}<0,05)$. Strain $S$. cerevisiae NRRL 12618 memiliki potensi untuk digunakan sebagai probiotic yeast. Suplementasi dengan strain ini mampu meningkatkan fermentabilitas dan kandungan isoacid dalam rumen serta menurunkan rasio A:P. Kemampuan ini dapat ditingkatkan jika probiotik S. cerevisiae dikombinasikan probiotik MR4.

Kata kunci: karakteristik fermentasi, probiotik, mikroba rumen, Saccharomyces cerevisiae

${ }^{*}$ Corresponding author:

E-mail: ipbsurya56@yahoo.co.id 


\section{INTRODUCTION}

The efforts to improve productivity and quality of beef cattle are still constrained by nutrition problem. The cattle kept in feedlot consume large amounts of concentrate compared to the amount of forage. High concentrate consumption can improve the accumulation of lactic acid by rumen bacteria and causing acidosis. Nutritionist has focused on the modification of rumen fermentation to improve productivity. Consequently, research has involved of diet such as supplementation with feed additive that have potential to modify the rumen environment (Calsamiglia et al., 2006). One of feed additive is probiotic. Probiotics are defined as live microbial feed supplements that have beneficial effect on the host animal by improving microbial balance in digestive tract. Supplementation with probiotic was aimed to increase the capacity of animal digestion. Probiotic in ruminant is used to modify the microorganism ecosystem and rumen fermentation. This method can be accomplished by manipulating microbial population to stimulate fiber and starch digestibility, improving volatile fatty acid (VFA) production and reduce lactate accumulation that can reduce rumen $\mathrm{pH}$.

One of microorganism that potential to serve as probiotic is Saccharomyces cerevisiae. Supplementation with live $S$. cerevisiae has been associated with stabilizing rumen $\mathrm{pH}$ through promotion of the use of lactic acid by lactate-utilizing bacteria (Seo et al., 2010), and competition with rumen bacteria for rapidly fermentable carbohydrate (Bach et al., 2007). S. cerevisiae cells are believed to eliminate trace of oxygen in the rumen thus helping oxygen-sensitive bacteria to grow (Marden et al., 2008). The effect of $S$. cerevisiae on this rumen microbes activities are vary depending on the type of strain used (Sullivan \& Bradford, 2011). Therefore, it is necessary to select some $S$. cerevisiae that can grow in the rumen fluid and stimulates the activity of rumen microbes. The ability of S. cerevisiae as probiotics can be improved by combining $S$. cerevisiae with rumen microbe isolates called MR4 isolate. MR4 isolate is anaerobic rumen microbe that has ability to increase population of rumen microbes. The objective of this study was to select three strains of probiotic S. cerevisiae and to evaluate the effect of $S$. cerevisiae and rumen bacteria isolate (MR4) supplementation and their combination on rumen fermentability and rumen microbial population.

\section{MATERIALS AND METHODS}

\section{Preparation of Saccharomyces cerevisiae Probiotic}

S. cerevisiae strain NBRC 10217 was obtained from Biotechnology Laboratory, Indonesian Institute of Science. Strain NRRL Y 567 and NRRL 12618 were obtained from IPB Culture Collection (IPBCC). The strain was grown on potato dextrose broth (PDB, Difco) and incubated for $48 \mathrm{~h}$ at $30^{\circ} \mathrm{C}$. Pure culture of $\mathrm{S}$. cerevisiae was added into rice flour with ratio $5 \mathrm{~mL}$ culture : $20 \mathrm{~g}$. The mixture is stirred until homogenized and incubated for $24 \mathrm{~h}$ at $30^{\circ} \mathrm{C}$. The population of S. cerevisiae was measured by bacteriological analytical manual (BAM).

\section{Encapsulation of MR4 Isolate Probiotic}

Encapsulation of MR4 isolate was modified based on Krasaekoopt et al. (2003). One hundred milliliter of Na-alginate $2 \%$ solution was added with $100 \mathrm{~mL}$ of $2 \%$ starch solution. The solution was mixed with MR4 culture that was grown in BHI medium while flowing in $\mathrm{CO}_{2}$. Then $200 \mathrm{~mL}$ of canola oil containing $0.2 \mathrm{~mL}$ lecithin was added into solution and homogenized for $20 \mathrm{~min}$. Two hundred milliliters of $0.1 \mathrm{M} \mathrm{CaCl}_{2}$ solution was added slowly. Oil and water were separated, and the beads were harvested by filtration. The beads were washed with $0.9 \%$ saline solution containing $5 \%$ glycerol. The beads were mixed with skim milk powder.

\section{Experiment 1: Selection of Saccharomyces cerevisiae as Probiotic in Vitro}

The purpose of this study was to select $S$. cerevisiae strain that capable of living in rumen fluid and stimulating the growth of rumen bacteria. The experiment was designed in $4 \times 5$ factorial randomized block design with 3 replications. The first factor was $S$. cerevisiae strain consisted of 4 treatments (without SC supplementation as control treatment, NBRC 10217, NRRL Y 567 and NRRL 12618) and the second factor was time of incubation consisted of 5 levels (0, 1, 2, 3, and $4 \mathrm{~h})$. In vitro fermentation was conducted according to the method of Tilley \& Terry (1963). Into each fermentation tube, 500 mg substrate, $40 \mathrm{~mL}$ McDougall buffer, and $10 \mathrm{~mL}$ rumen fluid were added. Fermenter tubes were flowed by $\mathrm{CO}_{2}$ for $30 \mathrm{~s}$ ( $\mathrm{pH}$ 6.5-6.9) and incubated in shaker water bath at temperature of $39^{\circ} \mathrm{C}$.

The ration contained $60 \%$ king grass forage and $40 \%$ concentrate mixture (cassava by product, rice bran, corn, groundnut meal, palm kernel meal, $\mathrm{CaCO}_{3^{\prime}}$ and $\mathrm{NaCl}$ ) (Table 1). Dosage of $S$. cerevisiae probiotic was $10^{10} \mathrm{cfu} / \mathrm{kg}$ ration. Rumen fluid was collected after $3 \mathrm{~h}$ feeding from the rumen of fistulated-Ongole crossbred cattle. After 0, 1, 2, 3, and $4 \mathrm{~h}$, rumen fluid samples were collected for measurement of population of $S$. cerevisiae and rumen bacteria.

\section{Experiment 2: Rumen Fermentability and Microbial Population}

The best strain from Experiment 1 was used as probiotic S. cerevisiae in Experiment 2 and combined with MR4 isolate. The experiment was designed in randomized block design with 4 treatment consisted of: $\mathrm{P} 0=$ basal feed for feedlot; $\mathrm{P} 1=\mathrm{P} 0+$ S. cerevisiae probiotic; $\mathrm{P} 2=\mathrm{P} 0+\mathrm{MR} 4$ isolate $\left(10^{7} \mathrm{cfu} / \mathrm{g}\right.$ ration $) ; \mathrm{P} 3=\mathrm{P} 0+$ probiotic $S$. cerevisiae + MR4 isolate. In vitro fermentation was conducted according to the method of Tilley \& Terry (1963). After $4 \mathrm{~h}$ of incubation, rumen fluid sample was collected for $\mathrm{NH}_{3}, \mathrm{VFA}$, protozoa and rumen bacterial population.

\section{Sampling and Measurement}

Population of $S$. cerevisiae was measured by bacteriological analytical manual (BAM). Population of ru- 
Table 1. Ingredient and nutrient composition of basal ration

\begin{tabular}{|c|c|}
\hline Item & Amount \\
\hline Forage : Concentrate & $60: 40$ \\
\hline \multicolumn{2}{|l|}{ Concentrate } \\
\hline Cassava by product (\%) & 30.00 \\
\hline Corn $(\%)$ & 17.00 \\
\hline Rice bran (\%) & 28.00 \\
\hline Palm meal (\%) & 12.00 \\
\hline Nut meal (\%) & 10.00 \\
\hline $\mathrm{NaCl}(\%)$ & 1.00 \\
\hline $\mathrm{CaCO}_{3}(\%)$ & 1.50 \\
\hline Buffer mineral $(\%)^{\mathrm{a}}$ & 0.50 \\
\hline \multicolumn{2}{|l|}{ Nutrient composition $^{\mathrm{b}}$} \\
\hline Dry matter $(\%)$ & 91.48 \\
\hline Ash (\% DM) & 9.84 \\
\hline Crude protein (\% DM) & 10.00 \\
\hline Ether extract (\% DM) & 3.00 \\
\hline Crude fiber (\% DM) & 31.54 \\
\hline Non-structural carbohydrate (NSC) ${ }^{c}(\%$ DM) & 45.62 \\
\hline
\end{tabular}

Note:

The requirement of beef cattle was based on Lalman (2001) with BW= $346.5 \mathrm{~kg}$ and daily gain $1 \mathrm{~kg} / \mathrm{head} / \mathrm{d}$.

abuffer mineral content were Ca 15\%, P 11\%, Cl 12\%, Na 8\%, Mg 1.7\%, Fe 250 ppm, Mn 138 ppm, Cu 100 ppm, Zn 65 ppm, I 15 ppm, Co 2 ppm, vitamin A $80000 \mathrm{IU} / \mathrm{kg}$, vitamin D $25000 \mathrm{IU} / \mathrm{kg}$, and vitamin E $1000 \mathrm{IU} / \mathrm{kg}$. ${ }^{b}$ Chemical composition was analyzed in Research Center for Biological Resources and Biotechnology, Bogor Agricultural University (2015).

${ }^{\mathrm{c}} \mathrm{NSC}=100-($ ash + crude protein + ether extract + crude fiber $)$

men bacteria were quantified by Ogimoto \& Imai (1981) method that used BHI medium. Growth rate of S. cerevisiae was measured by equation $\mathrm{Pt}=\mathrm{Po}_{\mathrm{e}} \mathrm{e}^{\mathrm{kt}}(\mathrm{Pt}=$ population in $\mathrm{t}$ hours, $\mathrm{Po}=$ population in 0 hours, $\mathrm{k}=$ constant of growth rate, and $\mathrm{t}=$ incubation time). The rumen $\mathrm{pH}$ was measured with $\mathrm{pH}$ meter. Concentration of $\mathrm{NH}_{3}$ was measured by Micro-diffusion Conway method (General Laboratory Procedures 1966). Total VFA concentration and molar proportions of VFA were analyzed by using gas chromatography (GC 8A, Shimadzu Crop, Kyoto, Japan, capillary column type containing 10\% SP-1200, $1 \% \mathrm{H}_{3} \mathrm{PO} 4$ on $80 / 100$ Cromosorb WAW and nitrogen as gas carrier) (General Laboratory Procedures 1966). Protozoa populations were counted with Fuch Rosenthal Counting Chamber $(4 \times 4 \times 0.2 \mathrm{~mm})$ under a microscope $(10 \times 10)($ Ogimoto \& Imai, 1981) .

\section{Statistical Analysis}

Data were tested by using Analysis of Variance (ANOVA) and the differences among treatments means were examined in Experiment 1 by Duncan's multiple range and in Experiment 2 by contrast orthogonal (Mattjik \& Sumertajaya, 2006).

\section{RESULTS AND DISCUSSION}

\section{Experiment 1: Selection of Saccharomyces cerevisiae as Yeast Probiotic in Vitro}

The result of Experiment 1 showed that there was interaction between $S$. cerevisiae strain and incubation time on $S$. cerevisiae population in rumen fluid $(\mathrm{P}<0.05)$. The treatment was NRRL 12618 in 4 hours incubation time. All of $S$. cerevisiae strain could grow in rumen fluid with different growth rates (Figure 1). NRRL 12618 strain showed the highest growth rate in rumen fluid with growth rate was $3.3 \% / \mathrm{h}$. The growth rate of NBRC 10217 and NRRL Y 567 strains in rumen fluid were $2.2 \% / \mathrm{h}$ and $2.3 \% / \mathrm{h}$, respectively. There was no $S$. cerevisiae growth on control treatment. It showed that $S$. cerevisiae counted in the rumen fluid originated from $S$. cerevisiae added in the beginning of incubation.

All of $S$. cerevisiae strains had the increased growth rate with the increased duration of incubation time. However, an increase in the growth rate of $S$. cerevisiae after $4 \mathrm{~h}$ was not yet known. The increasing population of $S$. cerevisiae in rumen fluid was caused by higher oxygen concentration in media, since one of the factors that affect the $S$. cerevisiae growth in rumen fluid was availability of oxygen in the rumen. Some of $S$. cerevisiae strain was adapted to anaerobic condition. This suggests that all strains are facultative anaerobe. Kawas et al. (2007) suggested that varying responses of yeast supplementation was attributed to the strain of the yeast and diet. Jurkovich et al. (2014) reported that the different yeast strains seemed to have different metabolic activities that were indicated by the different abilities to consume oxygen.

The effect of $S$. cerevisiae supplementation on the growth of rumen bacteria was presented in Figure 2. There was no interaction between $S$. cerevisiae strain and incubation time on the growth of rumen bacteria $(\mathrm{P}>0.05)$. Based on regression analysis, all treatment did not show the pattern of linear, quadratic and cubic growth $(\mathrm{P}>0.05)$. Based on mean growth, there were tendency that $S$. cerevisiae supplementation increased rumen bacteria, while control treatment decreased rumen bacteria. This result was caused by the fact that there was no $S$. cerevisiae supplementation that could reduce $\mathrm{CO}_{2}$ concentration during incubation in vitro that eventually decreased the activities of rumen bacteria. Treatment with S. cerevisiae strain NRRL 12618 had highest rumen bacteria population, as compared to $S$. cerevisiae strain NBRC 10217 and S. cerevisiae strains NRRL Y-567. Based on the highest growth rate in rumen fluid and the ability to stimulate rumen bacteria then $S$.

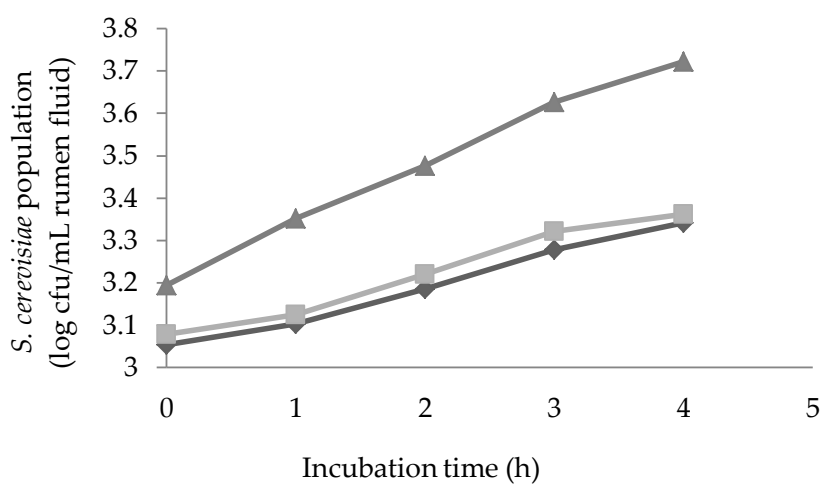

Figure 1. The growth of three S. cerevisiae strains (NBRC 10217 $-\downarrow-;$ NRRL Y 567, - - -; NRRL 12618, - $\Delta$-) in rumen fluid 


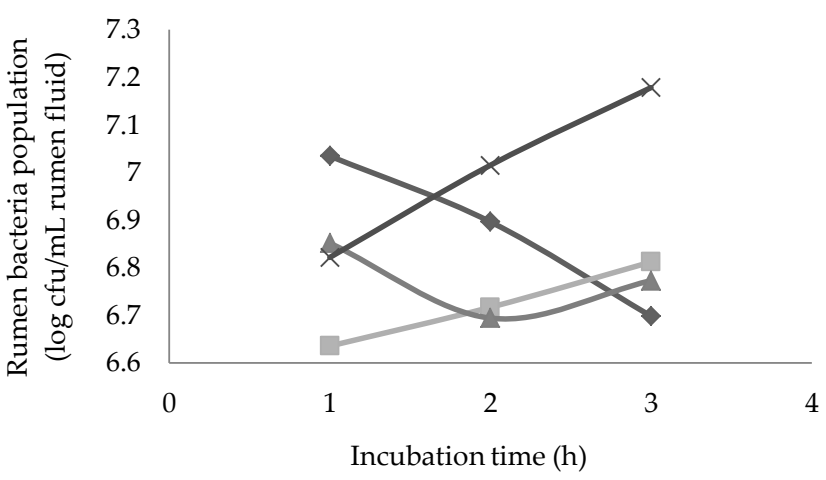

Figure 2. The growth of rumen bacteria supplemented with three S. cerevisiae strains (Control, - $\$$; NBRC 10217, -匹-; NRRL Y 567, - $\Delta$-; NRRL 12618, -x-)

cerevisiae strain NRRL 12618 was selected as probiotic yeast that would be used in Experiment 2.

The increase in population of rumen bacteria in the treatment of $S$. cerevisiae supplementation was caused by the ability of the $S$. cerevisiae to eliminate oxygen in the rumen to maintain its activity (Seo et al., 2010). Chaucheryas-Durand et al. (2008) reported that $S$. cerevisiae supplementation in ration could reduce redox potential of the rumen that eventually provided a better ecological condition for the growth and activity of anaerobic microorganisms in the rumen. Low redox potential stimulated the attachment of fibrolytic bacteria to cellulose particles and increased the initial rate of cellulolysis (Pinloche et al., 2013). Other factors that lead to high populations of rumen bacteria in S. cerevisiae supplementation treatment were the abilities of $S$. cerevisiae to produce and provide the growing factors such as organic acids and vitamins that eventually stimulate the growth of rumen bacteria population. Yeast supplementation significantly increased the relative occurrence of some rumen bacteria such as Megasphaera, Ruminococcus, Eubacterium, Selenomonas and Bifidobacterium and there was a tendency for Fibrobacter (Pinloche et al., 2013). It showed that live yeast supplementation increased the number and activity of bacterial population in the rumen.

\section{Experiment 2: Rumen Fermentability and Microbial Population}

Characteristics of rumen fermentation and microbial population were shown in Table 2. There was no different in rumen $\mathrm{pH}$ during $4 \mathrm{~h}$ incubation between control and probiotic supplementation. There was a tendency that probiotic $S$. cerevisiae had ability to maintain rumen $\mathrm{pH}$. It showed that probiotic supplementation could maintain normal $\mathrm{pH}$ with averages of 6.8-7. Rumen $\mathrm{pH}$ was in normal range and could stimulate rumen bacteria population. Yeast is able to compete against amylolytic bacteria that could prevent lactic acid accumulation in the rumen (Erasmus et al., 2005). Thrune et al. (2009) reported that dairy cow supplemented with yeast spent less in low $\mathrm{pH}(\mathrm{pH}<5.4)$ as compared to control.
Probiotic supplementation increased the concentration of ammonia $\left(\mathrm{NH}_{3}\right)$ in the rumen $(\mathrm{P}<0.05)$. The ability of single probiotic in producing $\mathrm{NH}_{3}$ in the rumen was similar to combination probiotics $(\mathrm{P}>0.05)$, while mean of $\mathrm{NH}_{3}$ concentration on P2 treatment was higher than P1 treatment i.e., $6.49 \mathrm{mM}$ and $5.95 \mathrm{mM}$, respectively. The lower concentration may be due to competition between yeast and the bacteria cells for energy supply and by direct inhibitory effect of yeast on small peptides and bacterial peptidases (Chaucheyras-Durand-Durand et al., 2008). Rohilla et al. (2009) reported that $\mathrm{NH}_{3}-\mathrm{N}$ was efficiently utilized by the addition of yeast in the ration. The low value of $\mathrm{NH}_{3}$ in the rumen is influenced by the low level of protein in the diet. $\mathrm{NH}_{3}$ is used as a source of $\mathrm{N}$ for microbial protein synthesis (Bach et al., 2005) so that the bacteria can grow in the rumen. The result showed that supplementation of single or combined probiotic could increase $\mathrm{NH}_{3}$ concentration in the rumen. $\mathrm{NH}_{3}$ is used for microbial protein synthesis to increase supply of post-rumen amino acids that are beneficial for the host.

The increase in $\mathrm{NH}_{3}$ concentration in P2 was assumed to be caused by the higher bacteria population. The $\mathrm{NH}_{3}$ concentration in this study was in line with the rumen bacteria population. Probiotic supplementation increased the populations of total rumen bacteria $(\mathrm{P}<0.05)$. The ability of single $(S$. cerevisiae or MR4) culture of probiotic was equal to that of co-culture probiotic (combination S. cerevisiae and MR4) in stimulating the growth of bacteria. The population of bacteria in P2 was higher than that of in P1 treatment i.e., $7.97 \mathrm{log} \mathrm{cfu} / \mathrm{mL}$ and $7.29 \log \mathrm{cfu} / \mathrm{mL}$, respectively. The highest population of rumen bacteria on P2 was caused by the fact that MR4 isolate itself is rumen bacteria. Malik \& Singh (2009) reported that yeast supplementation increased population of cellulose-degrading bacteria in the rumen. These results indicated that when conditions in the rumen were stabilized, there was an increase in the rate of fiber degradation through the increased activities of cellulolytic bacteria.

Probiotic supplementation decreased protozoa population in rumen during $4 \mathrm{~h}$ incubation time $(\mathrm{P}<0.05)$. The decreased population of protozoa in the group supplemented with probiotic was caused by the

Table 2. Fermentation characteristic and rumen microbe population in vitro from beef cattle supplemented with $S$. cerevisiae and rumen bacteria isolate (MR4) probiotics

\begin{tabular}{lcccc}
\hline \multirow{2}{*}{ Variable } & \multicolumn{4}{c}{ Treatments } \\
\cline { 2 - 5 } & $\mathrm{P} 0$ & $\mathrm{P} 1$ & $\mathrm{P} 2$ & $\mathrm{P} 3$ \\
\hline $\mathrm{pH}$ & $6.88 \pm 0.04$ & $6.96 \pm 0.15$ & $6.88 \pm 0.04$ & $6.92 \pm 0.11$ \\
$\mathrm{NH}_{3}(\mathrm{mM})$ & $5.73 \pm 0.30^{\mathrm{c}}$ & $5.95 \pm 0.77^{\mathrm{b}}$ & $6.49 \pm 0.23^{\mathrm{a}}$ & $6.26 \pm 0.18^{\mathrm{b}}$ \\
$\begin{array}{l}\text { Rumen bacteria } \\
\text { (log cfu/mL) }\end{array}$ & $7.04 \pm 0.76^{\mathrm{c}}$ & $7.29 \pm 0.81^{\mathrm{b}}$ & $7.97 \pm 0.47^{\mathrm{a}}$ & $7.67 \pm 0.66^{\mathrm{b}}$ \\
$\begin{array}{l}\text { Protozoa } \\
\text { (log sel/mL) }\end{array}$ & $3.98 \pm 0.11^{\mathrm{a}}$ & $3.79 \pm 0.13^{\mathrm{b}}$ & $3.80 \pm 0.14^{\mathrm{b}}$ & $3.78 \pm 0.23^{\mathrm{b}}$ \\
\hline
\end{tabular}

Note: P0 (basal ration); $\mathrm{P} 1$ ( $\mathrm{P} 0+$ S. cerevisiae probiotic), $\mathrm{P} 2(\mathrm{P} 0+\mathrm{MR} 4$ probiotic); $\mathrm{P} 3(\mathrm{P0}+\mathrm{S}$. cerevisiae probiotic $+\mathrm{MR} 4$ probiotic $)$. Means in the same row with different superscripts differ significantly $(\mathrm{P}<0.05)$. 
Tabel 3. Fermentation characteristic and rumen microbe population in vitro from beef cattle supplemented with S. cerevisiae and rumen bacteria isolate (MR4) probiotics

\begin{tabular}{lcccc}
\hline \multirow{2}{*}{ Variable } & \multicolumn{3}{c}{ Treatments } \\
\cline { 2 - 5 } & P0 & P1 & P2 & $110.36 \pm 0.88^{\mathrm{a}}$ \\
\hline Total VFA $(\mathrm{mM})$ & $101.05 \pm 5.41^{\mathrm{b}}$ & $115.53 \pm 17.88^{\mathrm{a}}$ & $52.80 \pm 0.85$ & $55.82 \pm 2.49$ \\
Acetate $(\mathrm{mM})$ & $50.46 \pm 3.39$ & $58.15 \pm 7.12$ & $36.17 \pm 1.75$ & $38.93 \pm 2.39$ \\
Propionate $(\mathrm{mM})$ & $34.71 \pm 3.54$ & $43.31 \pm 7.42$ & $10.77 \pm 0.42$ & $12.16 \pm 1.06$ \\
Butyrate $(\mathrm{mM})$ & $9.60 \pm 0.43$ & $12.51 \pm 2.01$ & $6.66 \pm 0.45$ & $7.26 \pm 0.74$ \\
Isobutyrate $(\mathrm{mM})$ & $6.13 \pm 1.14$ & $6.50 \pm 1.04$ & $0.71 \pm 0.25$ & $1.03 \pm 0.05$ \\
Valerate $(\mathrm{mM})$ & $0.66 \pm 0.21$ & $1.04 \pm 0.63$ & $2.79 \pm 0.96^{\mathrm{b}}$ & $3.93 \pm 0.65^{\mathrm{a}}$ \\
Isovalerate $(\mathrm{mM})$ & $1.98 \pm 0.87^{\mathrm{c}}$ & $1.89 \pm 0.52^{\mathrm{d}}$ & $1.46 \pm 0.08$ & $1.43 \pm 0.05$ \\
Acetate Propionate & $1.46 \pm 0.05$ & $1.35 \pm 0.10$ & & \\
\hline
\end{tabular}

Note: P0 (basal ration); P1 (P0 + S. cerevisiae probiotic), P2 (P0 + MR4 probiotic); P3 (P0 + S. cerevisiae probiotic + MR4 probiotic). Means in the same row with different superscripts differ significantly $(\mathrm{P}<0.05)$.

increased population of bacteria in the rumen fluid. The result of this observation showed that probiotic could be used as a defaunation agent. Kowalik et al. (2012) reported that supplementation of live $S$. cerevisiae decreased rumen protozoa, while supplementation of $S$. cerevisiae metabolite increased rumen protozoa. These results could be caused the availability of nutrients and metabolites released by the dead S. cerevisiae that could serves as prebiotic for the growth of rumen protozoa. S. cerevisiae contains soluble factors (vitamin B, amino acid, organic acids such as malic, fumaric and aspartate) and cell membrane of $S$. cerevisiae contains mannan and $\beta$-glucan that can stimulate the growth of Entodinium. Dobicki et al. (2006) reported that S. cerevisiae metabolite was able to increase population of Diplodinium spp. as compared with control treatment.

The effect of probiotic supplementation on VFA concentration was presented in Table 3. Probiotic supplementation increased total VFA concentration $(\mathrm{P}<0.05)$ but probiotic supplementation did not change molar proportion of acetate, propionate, and butyrate concentrations ( $\mathrm{P}>0.05)$. Combination of $S$. cerevisiae and MR4 probiotic had the same effect as single probiotic on VFA total concentration. The increase in total VFA concentration in the rumen was caused by the stability of rumen $\mathrm{pH}$ that eventually stimulated the growth of bacterial population. Desnoyers et al. (2009) concluded that yeast supplementation increased rumen $\mathrm{pH}$ and volatile fatty acid concentration. Isobutyric acid concentration was not affected by probiotic supplementation $(P>0.05)$. The growths of specific strains of fiber-digesting bacteria, which have major roles in the digestion of fiber to produced higher short chain fatty acid, were stimulated by yeast supplementation (Harikrishna et al. 2013). Probiotic supplementation increased isovalerate concentration $(\mathrm{P}<0.05)$. Combination of $S$. cerevisiae and MR4 probiotic increased isovalerate concentration $(\mathrm{P}<0.05)$. The high concentrations of isobutyrate and isovalerate showed the increased proteolytic activities in the group supplemented with $S$. cerevisiae so that proteolytic bacteria could utilize brach-chain amino acid as energy source to produce brach-chain fatty acid as the end product (Vyas et al., 2014). Isoacid (isobutyrate and isovalerate) concentrations increased with the addition of yeast culture (Lascano \& Heinrichs, 2009). Cellulolytic bacteria require isoacid from protein deamination to stimulate their growth and the capacity to degrade fiber. Probiotic supplementation had no effect on acetate to propionate ratio $(\mathrm{A}: \mathrm{P})(\mathrm{P}>0.05)$. All treatment had low A:P ratios indicating that propiogenic activity was more dominant in feed degradation. Besides the effect of stimulating $S$. cerevisiae on VFA concentrations, $S$. cerevisiae supplementation changed the molar proportion of VFA in the rumen to increase the glucogenic potential of the diet (lower A:P ratio). Probiotic supplementation is more effective, resulting in a higher A:P ratio (Guedes et al., 2008). The high concentration of propionate was caused by the high Propionibacteria, such as Meganosphera elsdenii and Selenomonas ruminantium, converting lactic acid into propionate (Silberberg et al., 2013). Propionate is a precursor for gluconeogenesis process, so the increase in propionate in the rumen could improve glucose synthesis from propionate in the liver (Stein et al., 2006).

\section{CONCLUSION}

Saccharomyces cerevisiae could grow in rumen fluid and increased rumen bacterial population. One of potential probiotic yeast was $S$. cerevisiae strain NRRL 12618. Combination of $S$. cerevisiae and rumen microbe probiotics increased rumen fermentability, isoacid concentration and decreased acetate : propionate ratio.

\section{ACKNOWLEDGEMENT}

This experiment was funded by Directorate General of Higher Education, Ministry of National Education of Indonesia through "BOPTN" grant 2015.

\section{REFERENCES}

Bach, A., S. Calsamiglia, \& M. D. Stern. 2005. Nitrogen metabolism in the rumen. Dairy Sci. 88: E9-E21. http://dx.doi. org/10.3168/jds.S0022-0302(05)73133-7

Bach, A., C. Iglesias., \& M Devant. 2007. Daily rumen pH pattern of loose-housed daily cattle as affected by feeding pattern and live yeast supplementation. Anim. Feed Sci. 
Technol. 136: 146-153. http://dx.doi.org/10.1016/j.anifeedsci.2006.09.011

Calsamiglia, S., L Catillejos, \& M. Busquet. 2006. Alternatives to antimicrobial growth promoters in cattle. In : Smith P., J. Wiseman (eds) Recent advances in animal nutrition. Nottingham University Press, Nottingham, pp 129-167. http:// dx.doi.org/10.5661/recadv-05-129

Chaucheyras-Durand, F., N. D. Walker, \& A. Bach. 2008. Effect of active dry yeast on the rumen microbiol ecosystem: past, present and future. Anim Fed Sci Technol. 145 : 5-26. http://dx.doi.org/10.1016/j.anifeedsci.2007.04.019

Desnoyers, M., S. Giger-Reverdin., G. Bertin., C. Duvaux-Ponter, \& D. Sauvant. 2009. Meta-analysis of the influence of Saccharomyces cerevisiae supplementation on ruminal parameter and milk production of ruminants. Dairy Sci. 92: 1620-1632. http://dx.doi.org/10.3168/jds.2008-1414

Dobicki, A., J. Pres., A. Zachwieja, \& R. Kwasnicki. 2006. Saccharomyces cerevisiae preparations in the feeding of cows and their effect on milk yield and composition as well as rumen microorganisms. Polish Agric Univ. $9: 4$.

Erasmus, L. J., P. H. Robinson, A. Ahmadi, R. Hinders, \& J. E. Garret. 2005. Influence of prepartum and post-partum supplementation of a yeast culture and monensin, or both on ruminal fermentation and performance of multiparous dairy cows. Anim Feed Sci and Technol. 122: 219-239. http://dx.doi.org/10.1016/j.anifeedsci.2005.03.004

General Laboratory Procedures. 1966. Department of Dairy Science. University of Wisconsin, Madison.

Guedes, C. M., D. Goncalves, M. A. M. Rodrigues, \& A. Diasda-Silva. 2008. Effect of Saccharomyces cerevisiae yeast on ruminal fermentation and fiber degradation of maize silage in cows. Anim. Feed Sci. Technol. 145: 27-40. http:// dx.doi.org/10.1016/j.anifeedsci.2007.06.037

Harikrishna, C. H., M. Mahander., Y. R. Reddy., M. G. Prakash., K. Sudhakar, \& M. Pavani. 2013. Supplentation effect of thermotolerant yeast on nutrient utilization and rumen fermentation in Nellore lambs. Livestock Research for Rural Development. 25(5).

Jurkovich, V., E. Brydl., J. Kutasi., A. Harnos., P. Kovacs, L. Konyves., Z. Muravolgyi, \& H. Febel. 2014. The effect of Saccharomyces cerevisiae strains on the rumen fermentation in sheep fed with diets of different forage to concentrate rations. J. Appl. Anim. Res. 42:481-486.

Kawas, W. R., R. Garcia-Castillo, F. Garza-Cazares, H. Fimbres-Durazo, E. Olivares-Saenz, G. Hernandez-Vidal, \& C. D. Lu. 2007. Effect of sodium bicarbonate and yeast on productive performance and carcass characteristics of high weight lambs fed finishing diets. Small Rumin. Res. 67: 157163. http://dx.doi.org/10.1016/j.smallrumres.2005.09.011

Kowalik, B., J. Skomial., J. J. Pajak., M. Taciak., M. Majewska, \& G. Belzecki. 2012. Population of ciliates, rumen fermentation indicators and biochemical parameters of blood serum in heifers fed diets supplemented with yeast (Saccharomyces cerevisiae) preparation. Animal Science Paper and Report. 30 : 329-338.

Krasaekoopt, W.B., Bhandari, \& H. Deeth. 2003. Evaluation of encapsulation techniques of probiotics for yoghurt. International Dairy Journal. 13: 3-13. http://dx.doi.org/10.1016/ S0958-6946(02)00155-3

Lalman, D. 2001. Nutrient Requirement of Beef Cattle. Oklahoma State University. USA.
Lascano, G. J. \& A. J. Heinrichs. 2009. Rumen fermentation pattern of dairy heifers fed restricted amount of low, medium, and high concentrate diets without and with yeast culture. Livestock Sci. 124 : 48-57. http://dx.doi.org/10.1016/j.livsci.2008.12.007

Malik, R. \& R. Singh. 2009. Effect of yeast and fungi culture on in vitro ruminal fermentation. Indian Journal of Animal Nutrition. 26: 40-45.

Marden, J. P., C. Julien, V. Monteils, E. Auclair, E. Moncoulon, \& C. Bayourthe. 2008. How does live yeast differ from sodium bicarbonate to stabilize ruminal $\mathrm{pH}$ in high-yielding dairy cows?. Dairy Sci. 91: 3528-3535. http://dx.doi. org/10.3168/jds.2007-0889

Mattjik, A.A \& M. Sumertajaya. 2006. Perancangan Percobaan dan Aplikasi SAS dan Minitab. Jilid I. Edisi ke 2. Bogor (ID): IPB Press.

Ogimoto, K \& S. Imai. 1981. Atlas of Rumen Microbiology. Japan Scientific Societies Press, Tokyo, 231 p.

Pinloche, E., N. McEwan., J.P. Marden., C. Bayourthe., E. Auclair, \& Newbold, C. J. 2013. The effect of probiotic yeast on bacterial diversity and population structure in the rumen of cattle. Plos One 8: e67824. http://dx.doi.org/10.1371/ journal.pone.0067824

Rohilla, P. P., N. V. Patil, \& H. C. Bohra. 2009. Effect of probiotics and nutri mix on kids and goat. Indian Veterinary Journal. 186: 640-649.

Seo, J. K., S. W. Kim, M. H. Kim, S. D. Upadhaya, D. K. Kam, \& J. K. Ha. 2010. Direct-fed microbials for ruminant Animals. Asian-Aust. J. Anim. Sci. 23: 1657-1667.

Silberberg, M., F. Chaucheyras-Durand, L. Commun, M. Mialon, V. Monteils, P. Mosoni, D. P. Morgavi, \& C. Martin. 2013. Repeated acidosis challenges and live yeast supplementation shape rumen microbiota and fermentations and modulate inflammatory status in sheep. Anim Feed Sci. 7: 1910-1920. http://dx.doi.org/10.1017/s1751731113001705

Stein, D. R., D. T. Allen, E. B. Perry, J. C. Bruner, K. W. Gates, T. G. Rehberger, K Mertz, D. Jones, \& L. J. Spicer. 2006. Effects of feeding propionibacteria to dairy cows on milk yield, milk components, and reproduction. Dairy Sci. $\quad 89: 111-125 . \quad$ http://dx.doi.org/10.3168/jds.S00220302(06)72074-4

Sullivan, M. L. \& B. J. Bradford. 2011. Viable cell yield from active dry yeast product and effects of storage temperature and diluent on yeast cell viability. Dairy Sci. 94: 526-531. http://dx.doi.org/10.3168/jds.2010-3553

Thrune, M., A. Bach, M. Ruiz-Moreno, M. D. Stern, \& J. G. Linn. 2009. Effect of Saccharomyces cerevisiae on Ruminal $\mathrm{pH}$ and microbial fermentation in dairy cows. Livestock Science. 124: 261-265. http://dx.doi.org/10.1016/j.livsci.2009.02.007

Tilley, J. M. A. \& R. A. Terry. 1963. A two-stage technique for the in vitro digestion of forage crops. British Grasslan Soc. 18: 104-111. http://dx.doi.org/10.1111/j.1365-2494.1963. tb00335.x

Vyas D., A. Uwizeye, R. Mohammed, W. Z. Yang, N. D. Walker, \& K.A. Beauchemin. 2014. The effect of active dried and killed dried yeast on subacute ruminal acidosis, ruminal fermentation, and nutrient digestibility in beef heifers. Anim Sci. 92 : 724-732. http://dx.doi.org/10.2527/jas.20137072 